$\mathbb{B}$

J. bio-sci. 22: 1- 8, 2014

ISSN 1023-8654

http://www.banglajol.info/index.php/JBS/index

\title{
DATURA METEL LINN AMELIORATES ASTHMA SYMPTOMS IN BALB/C MICE
}

\author{
Muhaimin Rifa'i *1, Dewi Satwika ${ }^{1}$, Aulanni'A M ${ }^{2}$ \\ 1 Biology Department, Faculty of Sciences, Brawijaya University, Malang 65145, Indonesia \\ ${ }^{2}$ Chemistry Department, Faculty of Sciences, Brawijaya University, Malang 65145, Indonesia
}

\begin{abstract}
Context: Datura has been recognized as viable alternate options to ameliorate asthma symptoms. Atropine contained in Datura is believed to be anti-asthmatic agent with its capacity to eliminate the spasms that cause asthma attacks. In Indonesian traditional medicine, the leaves of Datura are generally smoked either in cigarette or a pipe, and most asthma patients get benefit to relieve this disease.

Objective: The potentiality of Datura metel was tested to control immune response and ameliorate the disease in mouse models of asthma.

Materials and Methods: Mice were sensitized by twice intraperitoneal (i.p) injection with $10 \mu \mathrm{g}$ ovalbumin (OVA), then exposed to 1\% aerosolized OVA with nebulizer system. Mice then were orally treated by aqueous extract of $D$. metel $L$ for 5 days with a dose of $0.56 \mathrm{mg} / \mathrm{kg}$ body weight (BW) or 1.12 $\mathrm{mg} / \mathrm{kg} \mathrm{BW}$.

Results: The number of naiive $\mathrm{CD}^{+} \mathrm{T}$ cells $\left(\mathrm{CD} 4^{+} \mathrm{CD} 62 \mathrm{~L}^{+}\right)$increased in mouse model of asthma treated with $D$. Metel $\mathrm{L}$. In contrast, the number of $\mathrm{CD} 4^{+} \mathrm{CD} 25^{+} \mathrm{T}$ cells decreased in mouse model of asthma after treatment. Dose variations in this experiment had no significant effect $(p<0.05)$, and the optimum dose to reduce bronchioles thickness was $0.56 \mathrm{mg} / \mathrm{kg} \mathrm{BW}$.

Conclusion: $D$. metel $\mathrm{L}$. has a potential to ameliorate asthma symptom by promoting naïve $\mathrm{T}$ cell development and reducing activated $\mathrm{T}$ cells.
\end{abstract}

Key words: BALB/c mice, Asthma, Datura metel Linn, Regulatory T cells.

Introduction

Asthma is characterized by clinical symptoms of wheezing, chest tightness, dyspnea, cough, and by the presence of reversible narrowing airway and/or airway hyper responsiveness (AHR) to a variety of inhaled bronchoconstriction stimuli. People with asthma will increase in levels of T-helper-2 (Th-2) cytokines and undergo chronic airway inflammation and remodeling (Matt et al. 2009, Silva et al. 2010, Zhang et al. 2011). In that condition mast cells develop to an effector phase and produce Th2 cytokines, like IL-4, IL-5, and IL-9. Cell activation in turn contributes to the accumulation of pro-inflammatory cytokines. Activated $T$ cells will loss the expression of cell surface molecule and lead to the expression of other surface molecules, such as $\mathrm{CD}^{+}{ }^{+}, \mathrm{CD}_{25} 5^{+}$and $\mathrm{CD} 44^{+}$. Some previous studies show that activated memory CD4+ $\mathrm{T}$ cells has important role to produce Th2 cytokines in asthma. There is evidence that CD8 ${ }^{+} \mathrm{T}$ cells are able to promote Th2 cytokines secretion and contribute to allergic inflammation and airway sensitivity. Airway inflammation is also characterized by infiltration of lymphocytes and eosinophils in both bronchial epithelium and lamina propria (Seneviratneet et al. 2002, Rensen et al. 2005, Vignola et al. 2000, Knight et al. 2007, Machura et al. 2010). Mononuclear cell infiltration induces structural changes in the bronchial wall, often referred to "tissue remodeling". The features of airway remodeling in asthma include thickening airway smooth muscle layer. Herbs have been chosen because they are more secure and have less negative effect compared to modern drug. Some herbs have been identified to have a benefit to cure asthma. Datura stramoniams principle mechanism of action when the smoke is inhaled is anti-cholinergic bronchodilatation, with efficacy similar to

* Corresponding author E-mail: rifa123@ub.ac.id 
salbutamol via metered dose inhaler, although the duration of action is shorter. Lobelia inflate was introduced as a medication in 1813 and is a plant alkaloid with mixed antagonism to nicotinic acetyl-choline receptors. Apart from its principle mechanism of bronchial vasodilatation, it has been used as a nicotine substitute, as it acts on central dopaminergic systems. For these reasons it is often included in asthma cigarettes. Allergic inflammation in a mouse model of asthma can be ameliorated by blockage of growth factor production (Simon et al. 2010, Yan et al. 2012).

D. metel, commonly known as "Devil's Trumpet" or in Indonesia known as "Kecubung" is an herb able to cure various diseases and it is also recognized to have analgesic properties. It belongs to the family of Solanaceae widely used in phytomedicine to cure diseases such as asthma, cough, convulsion, and insanity (Wannanget et al. 2009, Kiruthika and Sornaraj 2011). According to Alexander et al. 2008 most Datura sp. contains high concentration of alkaloids. Anticholinergic activity of $D$. metel flower and seed is believed to relax airway smooth muscle, so that the responsiveness of airway decreases. However, D. metel also causes poisoning such as delirium, hallucination, dilated pupils, dry mouth, dry skin, hyperthermia, cardiac conduction abnormalities, and urinary retention (Murch et al. 2009). Indonesian people usually process herbs as "jamu"-a traditional medicine made by mixing some kinds of herbs, boiling or brewing them to get crude extract. In this study we observed the activity of T cell lymphocyte in mouse models of asthma and also examined the bronchial architecture after oral treatment with aqueous extract of $D$.metel.

\section{Materials and Methods \\ Experimental animal}

BALB/c mice (7 week-old male) were obtained from the Animal Center of Brawijaya University and maintained in our pathogen-free laboratory facility. The study complied with the recommendations of the Animal Care and Ethics Committee at Brawijaya University.

\section{Collection and identification of plant material}

D. metel flower were obtained from Sukun sub district, Malang City, Indonesia. The authentication of this plant is done by Plant Taxonomy Laboratory, Faculty of Sciences, Brawijaya University, Malang, Indonesia.

\section{Sensitization and inhaled exposure with OVA}

Mice were classified into asthma and non-asthma groups. Mouse models of asthma were obtained by twice intraperitoneal injections of $10 \mu \mathrm{g}$ ovalbumin (OVA, Sigma-Aldrich) with alum adjuvant on day 0 and 7 of the experiment. On the day 18, 21, and 24, mice were housed in chambers connected with Omron CompAir Compressor Nebulizer, and exposed to 1\% aerosolized OVA for 20 minutes per day. Non-asthma group only received physiological saline solution.

\section{Preparation of aqueous extract}

Dried flowers were cut down into tiny pieces by mortar and pestle. The weighed aliquot, about $0.28 \mathrm{mg}$, was put into $500 \mathrm{ml}$ sterile distilled water at $55^{\circ} \mathrm{C}$ for 24 hours by shaking to ensure homogeneity. The simplicia was then filtered separately using Whatman no.1 filter paper. The selected doses were $0.56 \mathrm{mg} / \mathrm{kg}$ BW and $1.12 \mathrm{mg} / \mathrm{kg} \mathrm{BW}$. Control groups received distilled water instead of $D$. metel extract as placebo. D. metel aqueous extract was given to the mice for 5 days.

\section{Flow cytometry analysis}

Mice were challenged with OVA on day 18, 21, and 24 executed1 day after the last challenge. Spleen cells were stained by FITC (fluorescent iso-thiocyanate) -conjugated anti-mouse CD4, PE(phycoerythrin) conjugated anti-mouse CD25, PE-conjugated anti-mouse CD8, and PE-conjugated anti-mouse CD62L in ice box $\left(4^{\circ} \mathrm{C}\right)$ for 30 minutes. Flow cytometry analysis was done by Cell Quest Pro software. 


\section{Preparation of histological specimens}

Lung and liver tissues were fixed by 4\% PFA, and processed for $\mathrm{H}-\mathrm{E}$ staining. Analysis was done by a microscope digital imaging (Microscope Olympus BX51 with Camera digital DP20).

\section{Statistical analysis}

Data were statistically analyzed by ONE-way ANOVA at $p<0.05$ and Tukey HSD test using SPSS 16.0 for Windows.

\section{Results}

\section{$T$ cells and Histological Architecture in Mice Model of Asthma}

OVA challenges induced allergic airway signed by an increase in the numbers of CD4+T cells (Fig.1). Relative numbers of $\mathrm{CD} 4^{+} \mathrm{T}$ cells in control group and treated mouse group were $10.60 \%$ and $25.33 \%$ respectively and absolute numbers were $12.09 \times 10^{6}$ and $20.18 \times 10^{6}$ respectively. OVA exposure induces proliferation and changes the status of naïve $\mathrm{CD}^{+} \mathrm{T}$ cells to an effector phase (Akbari et al. 2006). OVAchallenged mice developing to asthma will be safer from airway inflammation, eosinophil domination; and $\mathrm{CD}^{+} \mathrm{T}$ cells are markedly increased (Pimentel et al. 2010). In this experiment we found that the percentage of $\mathrm{CD}^{+}$also increased significantly after OVA challenge. Relative numbers of $\mathrm{CD} 8^{+} \mathrm{T}$ cells in control group and treated mice were $15.02 \%$ and $23.67 \%$ respectively and absolute numbers of CD8 ${ }^{+} T$ cells were $14.60 \mathrm{x}$ $10^{6}$ and $43.03 \times 10^{6}$ respectively.

a.

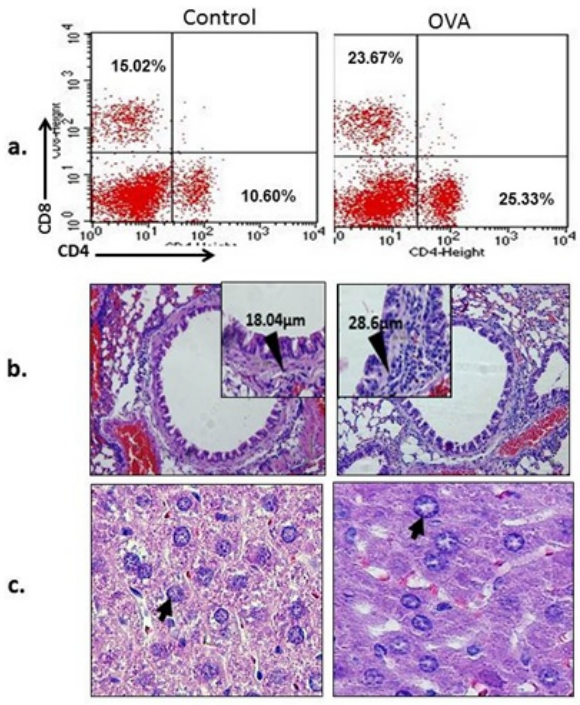

Fig.1. Ova challenge increased the number of T cells and the thickness of smooth muscle of bronchioles but it did not change the property of hepatocyte cells. (a) Mice were sensitized twice (i.p) on day 0 and 7 with ovalbumin (OVA). Intranasal challenge was administered on day 18, 21, and 24. Spleen cells were obtained from control group and treated group. Spleen cells were stained with FITC-conjugated anti-mouse CD4, PE-conjugated antimouse CD8 antibodies and analyzed by flow cytometry. Percentages of CD4 $4^{+}$or $\mathrm{CD} 8^{+} \mathrm{T}$ cells were shown in each panel. (b) Histological architecture of bronchioles and diameter of smooth muscle layer (insert) after H-E staining. (c) Histological architecture of liver stained by $\mathrm{H}-\mathrm{E}$ and hepatocytes were shown by an arrow. 


\section{D. metel ameliorates architecture of bronchioles in mice model of asthma}

In this study, we found that aqueous extract of $D$. metel could reduce the thickness of smooth muscle significantly. The thickness of smooth muscle in mice model of asthma reached $28.60 \mu \mathrm{m}$ before treatment. After administering aqueous extract of $D$. metel with doses of $0.56 \mathrm{mg} / \mathrm{kg} \mathrm{BW}$ and $1.12 \mathrm{mg} / \mathrm{kg} \mathrm{BW}$, the thickness of smooth muscle in mice model of asthma decreased to $12.76 \mu \mathrm{m}$ and $9.68 \mu \mathrm{m}$, respectively. This study confirmed the importance of $D$. metel in airway remodeling and extended results obtained from $\mathrm{BABL} / \mathrm{c}$ mice to make mouse models of asthma. In addition, we demonstrated that CD62L molecule underwent down regulation in mice exposure to OVA.

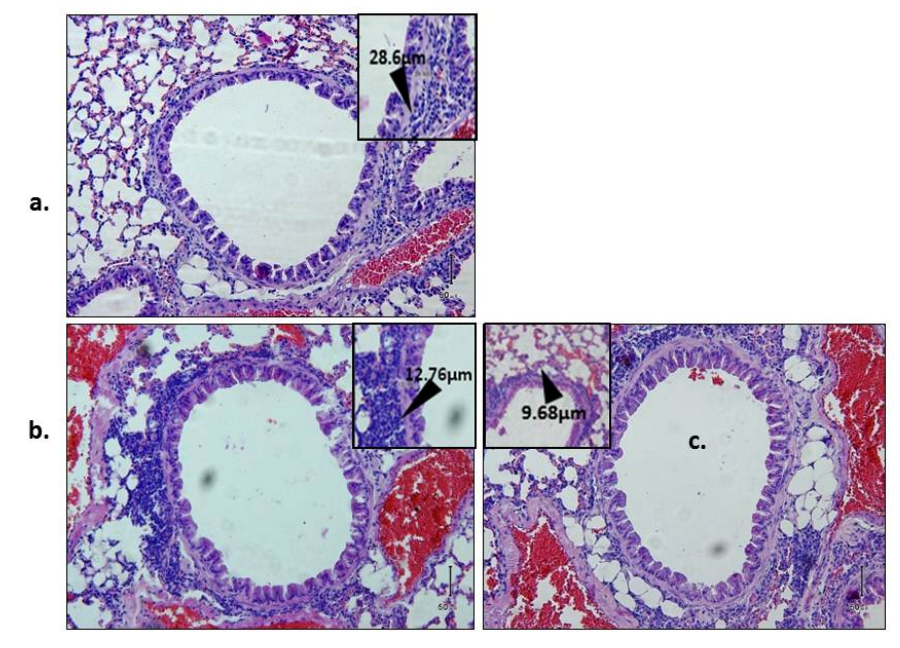

Fig. 2. Aqueous extract of $D$. metel $\mathrm{L}$ ameliorated bronchial architecture by normalizing the thickness of smooth muscle. Mouse models of asthma were treated by D. Metel L with the dose of $0.56 \mathrm{mg} / \mathrm{kg} \mathrm{BW}$ or $1.12 \mathrm{mg} / \mathrm{kg} \mathrm{BW}$ for each mouse. Histological analysis of bronchioles was done by H-E staining. (a) Mice model of asthma without treatment showed a thick smooth muscle $(28.6 \mu \mathrm{m})$. (b). After treated with $D$. metel $\mathrm{L}$ at the dose of $0.56 \mathrm{mg} / \mathrm{kg}$ BW the thickness of smooth muscle was $12.76 \mu \mathrm{m}$. (c) After treated with $D$.metel $\mathrm{L}$ at the dose $1.12 \mathrm{mg} / \mathrm{kg} \mathrm{BW}$ the thickness of smooth muscle was $9.68 \mu \mathrm{m}$. Results were the representative of two independent experiments with three mice per group.

\section{D. metel induced the development of naïve CD4 $T$ cells (CD4+CD62L $)$}

In this study we clearly showed that mice model of asthma were known to lose their CD62L molecule expression inCD4+ $\mathrm{T}$ cells (Fig. 3). Flow cytometry analysis revealed that relative number of $\mathrm{CD4}{ }^{+} \mathrm{CD} 62 \mathrm{~L}^{+} \mathrm{T}$ cells decreased significantly from $69.16 \%$ to $12.83 \%$ when asthma occurred. The absolute number of cell decreased from $19.25 \times 10^{6}$ cells (control group) to $8.35 \times 10^{6}$ cells (asthma group). The expression of Lselectin or CD62L significantly decreased in animal with asthma. In any conditions, mice treated by aqueous extract of $D$. metel at both doses of $0.56 \mathrm{mg} / \mathrm{kg} \mathrm{BW}$ and $1.12 \mathrm{mg} / \mathrm{kg} \mathrm{BW}$ showed significant increase in number of $\mathrm{CD4}{ }^{+} \mathrm{CD} 62 \mathrm{~L}^{+} \mathrm{T}$ cells compared to untreated mouse models of asthma (Fig. 3). 


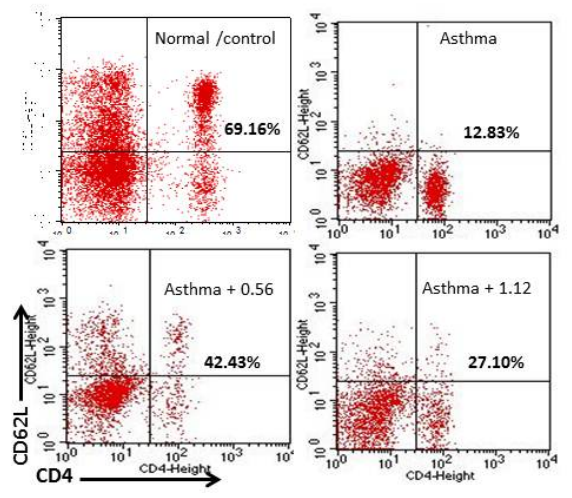

Fig. 3. Aqueous extract of $D$. metel $L$ changed the number of naïve $C D 4^{+} T$ cells $\left(C D 4^{+} C D 62 L^{+}\right)$in mouse models of asthma. Spleen was removed from normal mice (control), mouse models of asthma, and mouse models of asthma treated by $D$. metel L. Spleen cells were then isolated and stained by FITC-conjugated anti-mouse CD4 and PEconjugated anti-mouse CD62L and analyzed by flow cytometry. The percentage of CD62L $\mathrm{L}^{+}$cells (naive T cells) was shown in each panel. Upper left panel was obtained from normal mice. Upper right panel was obtained from mouse models of asthma without any treatments. Lower left panel was obtained from mouse models of asthma treated by 0.56 $\mathrm{mg} / \mathrm{kg} \mathrm{BW}$ of $D$. metel L. Lower right panel was obtained from mouse models of asthma treated by $1.12 \mathrm{mg} / \mathrm{kg} \mathrm{BW}$ of $D$. metel $\mathrm{L}$. Data were mean $\pm \mathrm{SD}$ values of three mice in each group.

\section{D. metel decreased the development of $C D 4^{+} C D 25^{+} T$ cells}

Mouse models of asthma hadCD4+CD25+ $T$ cells higher than normal ones (Fig. 4). In mouse models of asthma treated by $D$. metel at dose of $0.56 \mathrm{mg}$ and $1.12 \mathrm{mg} / \mathrm{kg}$ BW showed the decrease of CD4+CD25 $\mathrm{T}$ cells. The administration of $D$. metel aqueous extract reduced $\mathrm{CD} 4^{+} \mathrm{CD} 25^{+} \mathrm{T}$ cells significantly in mouse models of asthma. Relative numbers of CD4+CD25+T cells after administration of $D$.metel at dose of 0.56 and $1.12 \mathrm{mg} / \mathrm{kg}$ BW decreased from $28.28 \%$ to $20.23 \%$ and $8.87 \%$ respectively.

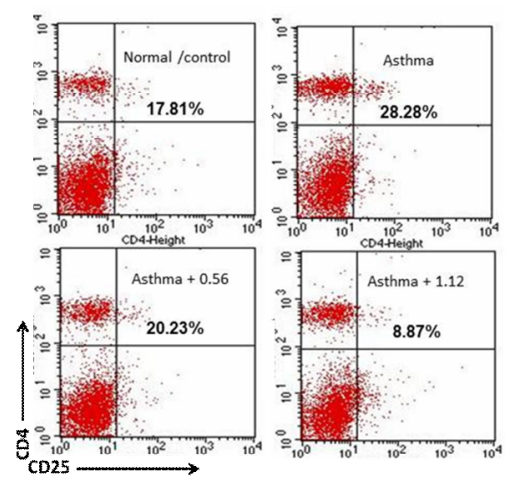

Fig. 4. Aqueous extract of D.metel $L$ changed the expression of $C D 25^{+}$molecules in CD4 $T$ cell in mouse models of asthma. Spleen was obtained from normal mice (control), mouse models of asthma, and mouse models of asthma treated by D.metel L. Spleen cells were then isolated and stained by FITC-conjugated anti-mouse CD4 and PEconjugated anti-mouse CD25 and analyzed by flow cytometry. Percentage of CD25+ cells (regulatory or memory T cells) was shown in each panel. Upper left panel was obtained from normal mice. Upper right panel was obtained from mouse models of asthma without any treatments. Lower left panel was obtained from mouse models of asthma treated by 0.56 $\mathrm{mg} / \mathrm{kg} \mathrm{BW} \mathrm{mg}$ of $D$. metel L. Lower right panel was obtained from mouse models of asthma treated by $1.12 \mathrm{mg} / \mathrm{kg} \mathrm{BW}$ of $D$. metel $\mathrm{L}$. Data were mean $\pm \mathrm{SD}$ values of three mice in each group. 
The absolute number of $\mathrm{CD} 4^{+} \mathrm{CD} 25^{+} \mathrm{T}$ cells in the same condition was $2.77 \times 10^{6}$. After the administration with doses of 0.56 and $1.12 \mathrm{mg} / \mathrm{kg} \mathrm{BW}$, absolute number of CD4+CD25+T cells became $2.81 \times 10^{6}$ and $1.34 \times 10^{6}$ cells respectively. Here we suppose that $\mathrm{CD} 4^{+} \mathrm{CD} 25^{+} \mathrm{T}$ cells in mouse model of asthma are not regulatory $\mathrm{T}$ cell but rather activated memory $T$ cell type. The decrease of $C D 4^{+} C D 25^{+} T$ cells consistent with the result that naivve type of $C D 4{ }^{+} C D 62 L^{+} T$ cells increase after $D$. metel administration.

\section{Discussion}

\section{$T$ cells and Histological Architecture in Mice Model of Asthma}

The increasing number of both CD4 and CD8 T cells after OVA challenge was consistent with the report stating that increasing number of $\mathrm{CD}^{+}$exacerbatedmouse models of asthma. $\mathrm{CD} 8^{+} \mathrm{T}$ cells regulated the secretion of proinflammatory cytokine such as IL-4, IL-5, and IL-9. Miyahara et al. (2004) states that the level of IL-13 and eosinophilic inflammation are lower in CD8-deficient mice compared to wild-type mice when observed in bronchoalveolar lavage fluid. These responses were restored by an adoptive transfer of antigen-primed CD8+. Besides increasing the level of $\mathrm{CD} 4^{+}$and $\mathrm{CD} 8^{+}$cells, we found that OVA challenge could change thickness of smooth muscle layer, from $18.04 \mu$ mto $28.6 \mu \mathrm{m}$. The airway remodeling in mouse models of asthma is characterized by structural changes, including mucus metaplasia, sub epithelial fibrosis, and smooth muscle hypertrophy / hyperplasia. In this experiment, however, structural changes were not found in liver tissue (Fig. 1c). $\mathrm{H}-\mathrm{E}$ stained liver tissue showed a normal architecture of hepatocyte. OVA challenge via airway did not influence other tissues, except bronchioles tissue. According to Rodolfo et al. 2007, OVA-sensitized mice can increase hyper responsiveness, eosinophilia inflammation, and smooth muscle thickness when supplemented by creatin. Besides that, mice challenged with OVA can up the regulated CD69 expression and secrete the cytokines such as IFN- $y$ and TNF-a (Enomoto et al. 2012).

This result indicated that T cell tended to be activated after OVA challenge. Based to our finding, we suggest that active compound dissolved in $D$. metel aqueous extract has a beneficial effect to relive the alveolar inflammation by normalizing bronchial architecture and regulating effector function on T cells. Additionally, we suggest that aqueous extract of $D$. metel, at both doses of $0.56 / \mathrm{kg} B W$ and $1.12 \mathrm{mg} / \mathrm{kg} \mathrm{BW}$ are able to cure mouse models of asthma by reducing smooth muscle thickness. This can be observed by looking the physical condition of mice after treatment. Treatment with doses of 0.56 and $1.12 \mathrm{mg} / \mathrm{kg}$ BW could ameliorate asthma symptoms. Histopathology examination of hepar showed the sign of necrotic cells at the dose of $1.12 \mathrm{mg} / \mathrm{kg} \mathrm{BW}$ but not at that of $0.56 \mathrm{mg} / \mathrm{kg} \mathrm{BW}$ (data not shown). Necrotic cells were characterized by condensed chromatin, shrinkage nuclei, pyknotic nuclei, and membrane integrity destruction. This result indicates that $D$. metel have a toxic effect in high dose and one should be careful to apply this herb for treatment in human. Although this herb has toxic effect, it is still interesting to be explored because the proper dosage is very beneficial as shown in mouse models of asthma.

In this experiment we showed that most CD4+ $\mathrm{T}$ cells in mouse models of asthma changed their status into the memory type and developed to the effector phase (Fig. 3). According to Rifa'l et al. $(2004,2013)$ activated CD4+ T cells in some circumstance also express other cell surface molecules such as $\mathrm{CD} 69^{+}, \mathrm{CD}^{+} 5^{+}$, and CD44+. In this experiment we showed that the dose of $0.56 \mathrm{mg} / \mathrm{kg} \mathrm{BW}$ was able to increase $\mathrm{CD4}{ }^{+} \mathrm{CD} 62 \mathrm{~L}^{+}$cell numbers up to $35.53 \times 10^{6}$ compared to those asthma groups, but there were no statistically differences between doses of 0.56 and $1.12 \mathrm{mg} / \mathrm{kg} \mathrm{BW}$.

$\mathrm{CD} 4^{+} \mathrm{CD} 25^{+} \mathrm{T}$ cells usually known as regulatory $\mathrm{T}$ cells are very important to maintain the homeostasis by suppressing activated cells. In this experiment we proposed that cells are activated memory rather than regulatory $T$ cells. The decrease of $C D 4^{+} C D 25^{+} T$ cells in mouse models of asthma after administering $D$. metel indicated that cells were not required to suppress activated cells. Most $T$ cell in mouse models of asthma changed the status from activated to naiive type after the treatment. The decrease of $C D 4^{+} C D 25^{+} T$ cells after treatment with $D$. metel indicated that $\mathrm{CD} 25$ in $\mathrm{CD} 4^{+} \mathrm{T}$ cells functioned as effector molecules rather than regulatory ones. That was why after most $T$ cells were dominated by naïve type, the number of $C D 4^{+} C D 25^{+} T$ cells decreased significantly. 


\section{Conclusion}

D. metel had pharmacological activities signed by its ability to ameliorate architecture of bronchioles in mice model of asthma. This herbal medicine may serve as an immunomodulator agent by reducing the number of activated $T$ cells and maintaining $T$ cells in naïve type status. $C D 4^{+} C D 25^{+} T$ cells in mice model of asthma reflexed as activated T cells and the number decreased after $D$. metel administration. $D$. metel ameliorate mice model of asthma by improving bronchial architecture and normalizing the thickness of smooth muscle.

\section{Acknowledgement}

The authors are grateful to Indonesian Ministry of Higher Education for providing financial support to carry out this work. Thanks to Brawijaya University Malang, Indonesia, for providing study necessities, and the members of Physiology Laboratory for experimental assistance.

\section{References}

Akbari O, John M D, Faul E G, Hoyte GJ, Berry J, Wahlström M, Kronenberg RH, DeKruyff,Umetsu D T. 2006. CD4+Invariant T-Cell-Receptor ${ }^{+}$Natural Killer T Cells in Bronchial Asthma. The New England Journal of Medicine 354(11), 1117-1129. http://dx.doi.org/10.1056/NEJMoa053614

Alexander J, Benford D A, Cockburn J P, Cravedi, Dogliotti E A E, Domenico M R, Férnandez-Cruz, Fürst P, FinkGremmelsJ,Galli C L, Grandjean P, Gzyl J, Heinemeyer G, Johansson N A, Mutti J, Schlatter, Leeuwen R, Peteghem C V, dan Verger P. 2008. Tropane Alkaloids (From Datura sp.) as Undesirable Substances in Animal Feed. The EFSA Journal 691, 1-55.

Enomoto N, Hyde E, Yang M J Z, Blom E F, Delahunt B, Gros L, Ronchese F. 2012. Allergen-specific CTL require perforin expression to suppress allergic airway inflammation. $J$ Immunol 188(4), 1734-1741. http://dx.doi.org/10.4049/jimmunol.1102699

Kiruthika K A, Sornaraj R. 2011. Screening of bioactive components of the flower Datura metel Linn.using the GC-MS technology. International J Pharm Tech 3(4), 2025-2028.

Knight A K, Blazquez A B, Zhang S, Mayer L, Sampson H A, Berin M C. 2007. CD4 T cells activated in the mesenteric lymph node mediate gastrointestinal food allergy in mice. Am J Physiol Gastrointest Liver Physiol 293(6), 12341243. http://dx.doi.org/10.1152/ajpgi.00323.2007

Machura E, Mazur B, Zychma M R, Czarneckal M B. 2010. Cytokine Production by Peripheral Blood CD4 ${ }^{+}$and CD8 ${ }^{+}$T Cells in Atopic Childhood Asthma. Hindawi Publishing Corporation. Clinical and Developmental Immunology ID 606139. $11 p$

Matt H, Creel A, Estell K, Davis I C, Schwiebert L M. 2009. Acute Exercise Decreases Airway Inflammation, but Not Responsiveness, in an Allergic Asthma Model. Am J Respir Cell Mol Biol 40(1), 83-89. http://dx.doi.org/10.1165/rcmb.2008-01720C

Miyahara N, Swanson B J, Takeda K, Taube C, Miyahara S, Kodama T, Dakhama A, Ott V L, Gelfand E W. 2004. Effector $\mathrm{CD}^{+} \mathrm{T}$ cells mediate inflammation and airway hyper-responsiveness. Nat Med 10(8), 865-869. http://dx.doi.org/10.1038/nm1081

Murch J M, Alan A R, Cao J, dan Saxena P K. 2009. Melatonin and Serotonin in Flowers and Fruits of Datura metel L. Journal of Pineal Research 47, 277-283. http://dx.doi.org/10.1038/nm1081

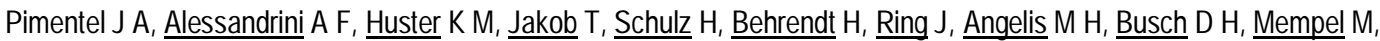
Ollert M. 2010. Specific CD8 T cells in IgE-mediated allergy correlate with allergen dose and allergic phenotype. American j. respiratory and critical care medicine 181(1), 7-16. http://dx.doi.org/10.1164/rccm.200902-01900C

Rensen E L J, Sont J K, Evertse C E, Willems L N A, Mauad T, Hiemstra P S, Peter J. 2005. Bronchial CD8 Cell Infiltrate and Lung Function Decline in Asthma. Am J Respir Crit Care Med 172, 837-841. http://dx.doi.org/10.1164/rccm.200504-6190C 
Rifa'i M, Kawamoto Y, Nakashima I, Suzuki H. 2004. Essential Roles of CD8 ${ }^{+} C D 122^{+}$Regulatory $T$ cells in the Maintenance of $T$ Cell Homeostasis. J Experimental Medicine 200(9), 1123-1134. http://dx.doi.org/10.1084/jem.20040395

Rifa'l M. 2013. CD4 ${ }^{+}$CD25 $5^{+}$Regulatory T Cells Preventing Detrimental Autoimmune Reactions. The Open Autoimmunity Journal $5,1-5$

Rodolfo P V, Claudia R C, Duarte A C S, Santos A B G, Perini A, Neto H C C F, Mauad T, Martins M A, Dolhnikoff M, Carvalho C R F. 2007. Aerobic exercise decreases chronic allergic lung inflammation and airway remodeling in mice. American Respiratory and Critical Care Medicine 176(9), 871-877. http://dx.doi.org/10.1164/rccm.200610$\underline{15670 C}$

Rodolfo P V, Duarte A C S, Claudino RC, Perini A, Santos A B G, Moriva H T, Costa V M A, Martin M A, Carvalho CRF, Dolhnikoff M. 2007. Creatine Supplementation Exacerbates Allergic Lung Inflammation and Air way remodeling in Mice.Am J Respir Cell MolBiol 37, 660-667. http://dx.doi.org/10.1165/rcmb.2007-01080C

S L, Jones L, Kingetal A S. 2002. Allergen-specific CD8 ${ }^{+}$T cells and atopic disease. Journal of Clinical Investigation 110(9), 1283-1291. http://dx.doi.org/10.1172/JCI0215753

Silva R A, Vieira R P, Duarte A C S. 2010. Aerobic training reverses airway inflammation and remodeling in an asthma murine model. European Respiratory Journal 35(5), 994-1002. http://dx.doi.org/10.1183/09031936.00049509

Simon F, Usmani O S, Polkey M I, Hopkinson N S. 2010. Emphysema due to smoke from an herbal asthma remedy. JRMM1 1, 1-8.

Vignola A M, Kips J, Bousquet. 2000. Tissue remodeling as a feature of persistent asthma. J Allergy Clin Immunol 105, 1041-1053. http://dx.doi.org/10.1067/mai.2000.107195

Wannang NN, Ndukwe HC, Nnabuife C. 2009. Evaluation of the analgesic properties of the Datura metel Linn seeds aqueous extract. Journal of Medicinal Plants Research 3(4), 192-195.

Yan S, Jin Y, Weiying Guo, Chen L Chaoying, Liu Xiaohong. 2012. Blockage of nerve growth factor modulate T cell responses and inhibits allergic inflammation in mouse model of asthma. Inflammation research Springer 61(12), 1369-1378.

Zhang F, Huang G, Bo Hu, Song Y, Shi Y. 2011. Induction of Immune Tolerance in Asthmatic Mice by Vaccination with DNA Encoding an Allergen-Cytotoxic T Lymphocyte-Associated Antigen 4 Combination. Clin Vaccine Immunol 18(5), 807-814. http://dx.doi.org/10.1128/CVI.00434-10 